\title{
Glioblastoma Following Radiotherapy in a Patient with Tuberous Sclerosis
}

\author{
-Case Report- \\ Hirotaka Matsumura, Hiroshi Takimoto, Nobumitsu Shimada, \\ Masayuki Hirata, Takanori OHNishi* , and Toru HAYAKAWA* \\ Department of Neurosurgery, Suita Municipal Hospital, Suita, Osaka; \\ *Department of Neurosurgery, Osaka University Medical School, Suita, Osaka
}

\begin{abstract}
A 26-year-old male with tuberous sclerosis developed a glioblastoma in the right temporal lobe 8 years after surgical excision and irradiation of a subependymal giant cell astrocytoma. The glioblastoma was probably an irradiation-induced tumor. Irradiation should not be given routinely for subependymal giant cell astrocytoma.
\end{abstract}

Key words: subependymal giant cell astrocytoma, tuberous sclerosis, irradiation-induced glioma

\section{Introduction}

Subependymal giant cell astrocytoma is the most common tumor associated with tuberous sclerosis. Such tumors are usually benign and situated near the foramen of Monro. Treatment is indicated only when the mass causes increased intracranial pressure by obstruction of the cerebrospinal fluid (CSF) pathway. Surgery usually is effective, whereas indications for adjunctive radiotherapy remain controversial. Radiotherapy is very important in the treatment of intracranial tumors, but may induce malignant neoplasms in both experimental animals and humans. ${ }^{12]}$ We describe the occurrence of glioblastoma in a patient with tuberous sclerosis who had received radiotherapy for subependymal giant cell astrocytoma 8 years before.

\section{Case Report}

A 26-year-old male had first been treated for tuberous sclerosis manifesting as facial adenoma sebaceum and intracranial calcifications at the age of 11 years. He had experienced no seizures and showed no mental retardation. His family history was noncontributory. In May 1987, when aged 18 years, he presented with complaints of headache and nausea for 1 month. Computed tomography (CT) revealed obstructive hydrocephalus caused by an intraventricular tumor near the right foramen of Monro. The tumor was partially removed by a transcallosal approach to decrease intracranial pressure. Histological examination of the tumor showed a typical subependymal giant cell astrocytoma consisting of large gemistocytic astrocytes and small spindleshaped cells with no malignant features (Fig. 1 upper). He underwent ventriculoperitoneal (VP) shunting 10 days after the surgery, because of incomplete resolution of hydrocephalus. Subsequently he received $50 \mathrm{~Gy}$ of radiation delivered by a linear accelerator as adjuvant therapy. The whole brain received $40 \mathrm{~Gy}$ in 20 equal fractions utilizing $20 \times 16$ $\mathrm{cm}$ laterally opposed fields, and $10 \mathrm{~Gy}$ was delivered in five equal fractions to limited $8 \times 9 \mathrm{~cm}$ fields centered at the foramen of Monro. He was free of symptoms for 8 years.

He returned to our hospital complaining of headache in February 1995. Neurological examination was normal, but magnetic resonance (MR) imaging showed a large round mass in the right temporal

Received September 17, 1997; Accepted February 18, 1998

Author's present address: H. Matsumura, M.D., Department of Neurosurgery, Osaka University Medical School, Suita, Osaka, Japan. 


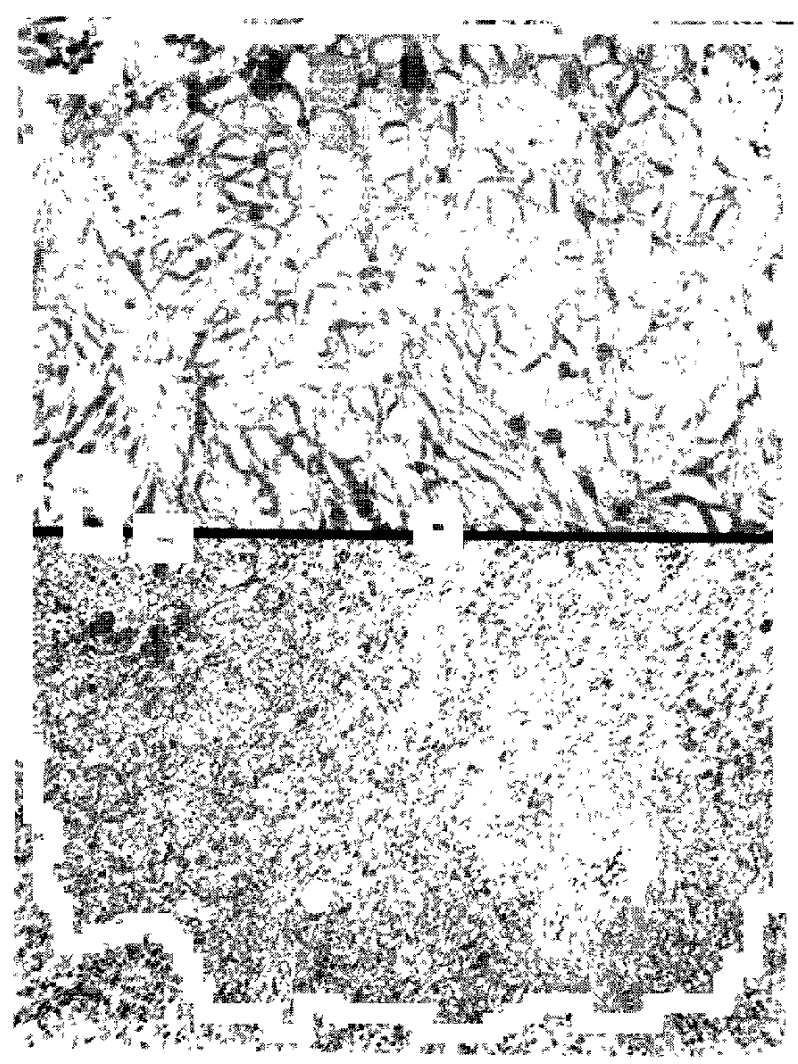

Fig. 1 upper: Photomicrograph of the first surgical specimen showing the pattern for typical subependymal giant cell astrocytoma, with two types of cells, one with abundant gemistocytic cytoplasm and the other with a spindle shape and bipolar processes. HE stain, $\times 200$. lower: Photomicrograph of the second surgical specimen showing the typical highly cellular appearance of glioblastoma, including endothelial proliferation and necrosis surrounded with pseudopalisading tumor cells. The pleomorphic tumor cells include many cells with mitotic figures or multinucleation. HE stain, $\times 100$.

lobe, which was not shown on MR imaging in January 1994. The tumor was well demarcated with inhomogeneous enhancement (Fig. 2 left). The tumor at the right foramen of Monro was unchanged (Fig. 2 right). Right internal carotid angiography revealed no abnormality such as tumor stain and early venous filling.

Gross total removal of the right temporal tumor was performed via a right temporal craniotomy. Histological examination showed the features of glioblastoma, including endothelial proliferation, necrosis, nuclear pleomorphism, and many mitotic figures (Fig. 1 lower). Immunocytochemical stain-

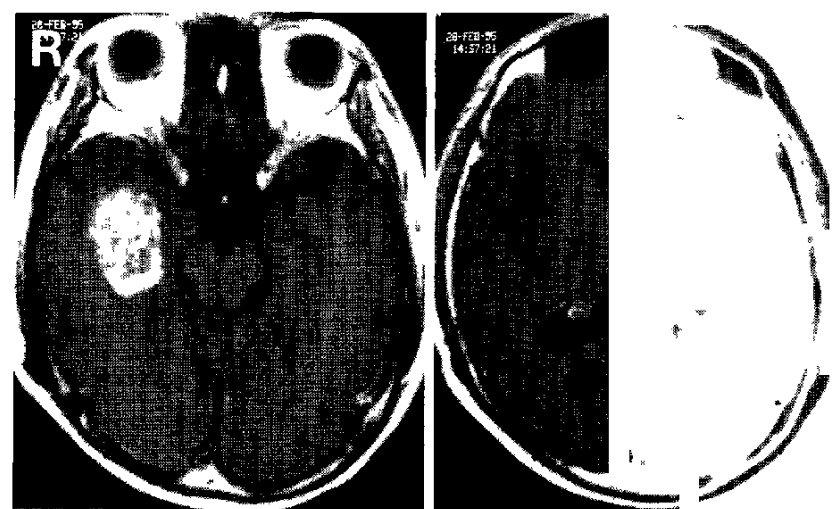

Fig. $2 T_{1}$-weighted magnetic resonance images after enhancement with gadoliniumdiethylenetriaminepenta-acetic acid performed at the second admission, demonstrating a large mass in the right temporal lobe with heterogeneous enhancement (left). The tumor at the right foramen of Monro is unchanged (right).

ing $^{7,8]}$ showed the tumor cells were positive for glial fibrillary acidic protein and Ki-67 (MIB-1 antibody), but not p53 (Pab240 and Pab1801 antibodies) (Fig. 3).

Intra-arterial chemotherapy with ACNU (nimustine) was given using a dose of $75 \mathrm{mg}$. MR imaging 4 months after treatment revealed recurrence of tumor in the right temporal lobe, which progressed and the patient died in January 1996. No autopsy was performed.

\section{Discussion}

Tuberous sclerosis, one of the phakomatoses, is also called Bourneville's disease. ${ }^{2)}$ The characteristic triad of main features is facial adenoma sebaceum, seizures, and mental retardation. Other organs including skin, eye, kidney, and lung may be affected in addition to the central nervous system. ${ }^{4,6)}$ Inheritance is autosomal dominant, with a high mutation rate. The estimated incidence is 1 in 10,000 to 1 in $50,000 .{ }^{27]}$

The main features of tuberous sclerosis in the central nervous system are cortical tubers, subependymal nodules, and calcifications. CT and MR imaging show cortical tubers in $88 \%$ of cases, subependymal nodules in $96 \%$, and calcifications in $88 \% .{ }^{1)}$ Brain tumors associated with tuberous sclerosis are relatively uncommon, occurring in $6 \%$ to $14 \%$ of cases. ${ }^{1,11,23)}$ The most common brain tumors are subependymal giant cell astrocytomas near the foramen of Monro. Histological and imaging studies have shown that subependymal giant cell astrocyto- 


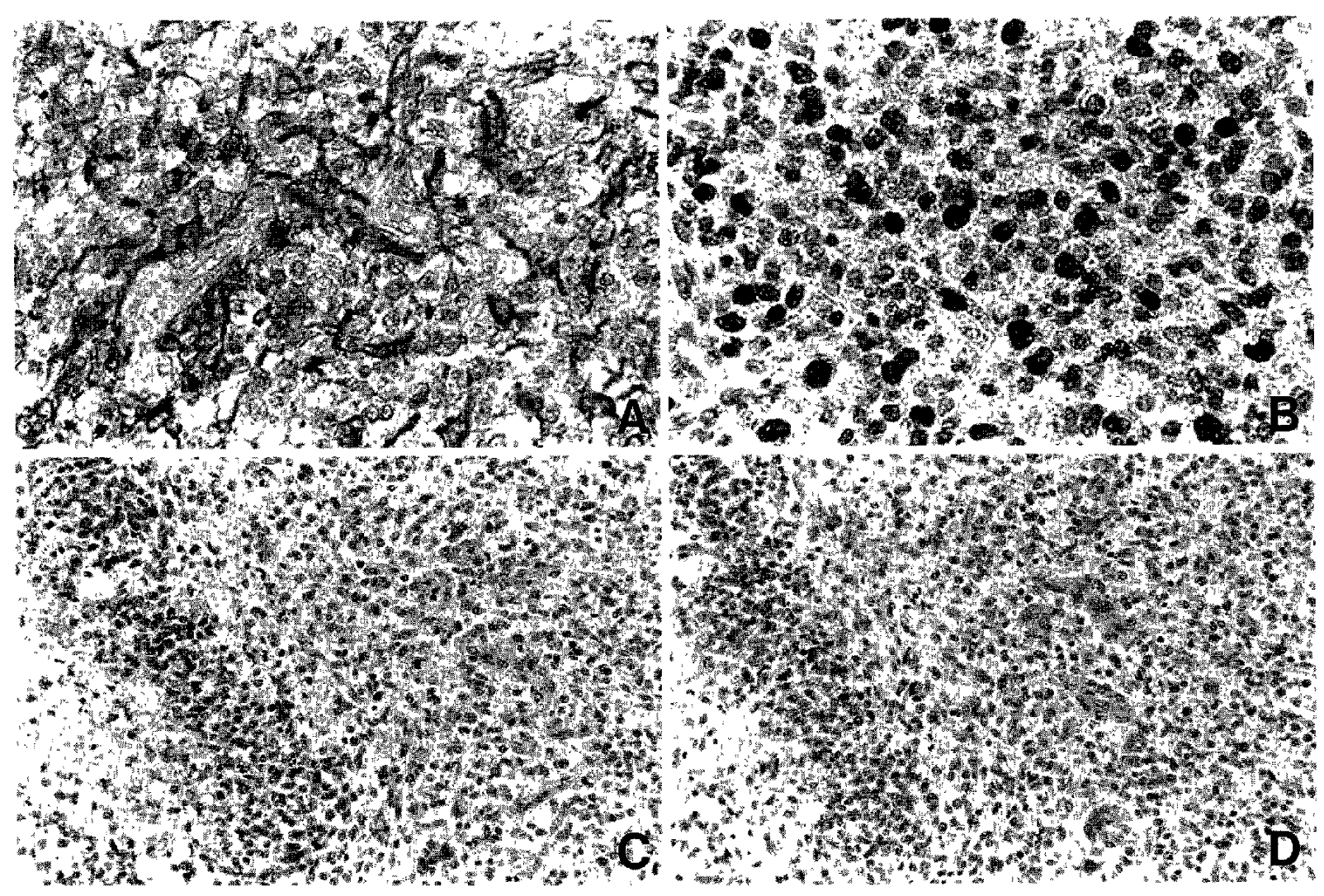

Fig. 3 Immunohistochemical staining of the glioblastoma specimen. The tumor cells are stained by the anti-glial fibrillary acidic protein antibody $(A: \times 400)$. About $35 \%$ of tumor cells are stained with anti-Ki67 antibody (B: $\times 400)$. No tumor cells are stained with either anti-p53 antibody (C: Pab240, × 200; D: Pab1801, × 200).

ma probably arises from subependymal nodules..$^{5,15}$ Other types of tumors are usually located remote from the foramen of Monro, and include astroblastoma, hemangioma, oligoastrocytoma, astrocytoma, spongioblastoma, neurinoma, and ependymoma. ${ }^{10,14,18,24,26)}$

Direct excision and CSF shunting are the two main surgical options for symptomatic subependymal giant cell astrocytoma in patients with tuberous sclerosis, but complete surgical resection is the optimum treatment. Shunting, usually not required after resection, is generally reserved for unresectable tumors causing increased intracranial pressure. The indications and effectiveness of postoperative radiotherapy are controversial, ${ }^{21)}$ In our case, postoperative radiotherapy was performed after partial removal and VP shunting. Although the subependymal giant cell astrocytoma had ceased to grow, glioblastoma occurred de novo 8 years later in the right temporal lobe, which was included in the irradiation field. It is possible that there is a relation between occurrence of the malignant tumor and the radiotherapy, taking the following characters into account. Firstly, the tumor fulfills the three criteria for radiation-induced tumors: tumor origin in the irradiation field, histological appearance differing from the lesion irradiated, and sufficient latency between irradiation and emergence of the radiationinduced tumor. ${ }^{20,22)}$ Secondly, spontaneously occurring malignant glioma in patients with tuberous sclerosis is very rare, which supports this hypothesis., ${ }^{3,17)}$ Thirdly, tuberous sclerosis has a tumor diathesis.

Oncogenetic sequences in glioblastoma multiforme supported by gene alterations in gliomas imply the possible involvement of at least two genetic pathways. ${ }^{13)}$ Firstly, glioblastomas may occur by multistage progression from low-grade astrocytomas initiated by mutation of the p53 gene in precursor cells. Secondly, glioblastomas may arise de novo without p53 alterations. Most of the second type of tumors show amplification of the epidermal growth factor receptor gene, and may also show loss of heterozygosity for chromosome 10. Clinically, patients in this group have a worse prognosis than patients with glioblastoma of the multistage-progression 
type. The tumor specimen in our case was not stained by either of the two antibodies which recognize mutant p53 proteins (Fig. 3C, D). MR imaging 13 months before admission did not show the presence of any tumor in the right temporal lobe. These data suggest that the glioblastoma may have occurred de novo. MIB-1 immunostaining in this glioblastoma showed an extremely high staining in$\operatorname{dex}(35 \%)$ (Fig. 3B), which indicates a very poor prognosis.

The main indication for treatment of subependymal giant cell astrocytoma in tuberous sclerosis is to relieve obstruction of CSF flow. Resection cannot improve epilepsy or mental retardation. Direct surgery is the most reliable and presently recommended therapy. ${ }^{19]}$ CSF shunting was favored because of surgical risks and slow tumor growth. ${ }^{9,26]}$ However, high levels of CSF protein may pose a major risk of shunt malfunction. ${ }^{19]}$ The outcome of surgery has also improved due to microsurgical techniques. Although irradiation was given to the present case in expectation of a favorable effect, radiotherapy and chemotherapy for subependymal giant cell astrocytoma are not generally recommended, particularly since malignant transformation and recurrence are uncommon, and no adjuvant therapy has been effective. ${ }^{16,25)}$ It has been reported that a case of subependymal giant cell astrocytoma with rapid growth showed no response to radiotherapy, requiring a second operation. ${ }^{25}$ ]

The World Health Organization glioma classification categorizes subependymal giant cell astrocytoma as grade 1 astrocytoma. Symptomatic patients with subependymal giant cell astrocytoma related to tuberous sclerosis are generally young. As a phakomatosis, tuberous sclerosis is associated with tumor diathesis. Therefore, radiotherapy should not be given for subependymal giant cell astrocytoma in patients with tuberous sclerosis except in special cases.

\section{References}

1) Altman NR, Purser RK, Post MJD: Tuberous sclerosis: Characteristics at CT and MR imaging. Radiology 167: 527-532, 1988

2] Bourneville DM: Sclerose tubereuse des circonvolutions cerebrales: Idiotie et epilepsie hemiplegique. Arch Intern Neurol 1: 81-91, 1880

3) Brown JM: Tuberous sclerosis with malignant astrocytoma. Med J Aust 1: 811-814, 1975

4) Dotan SA, Trobe JD, Gebarski SS: Visual loss in tuberous sclerosis. Neurology 41: 1915-1917, 1991

5) Fujiwara S, Takaki T, Hikita T, Nishio S: Subependymal giant-cell astrocytoma associated with tuberous sclerosis: Do subependymal nodules grow?
Childs Nerv Syst 5: 43-44, 1989

6) Golji H: Tuberous sclerosis and renal neoplasms. I Urol 85: 919-923, 1961

7) Higuchi M, Ohnishi T, Arita N, Hiraga S, Hayakawa $\mathrm{T}$ : Expression of tenascin in human gliomas: Its relation to histological malignancy, tumor dedifferentiation and angiogenesis. Acta Neuropathol (Berl) 85: 481-487, 1993

8) Hsu SM, Raine L, Fanger H: Use of avidin-biotin peroxidase complex $(A B C)$ in immunoperoxidase techniques: A comparison between $\mathrm{ABC}$ and unlabeled antibody (PAP) procedures. I Histochem Cytochem 29: 577-580, 1981

9) Itoyama $Y$, Matsukado $Y$, Nonaka N, Sano Y, Kuratsu J, Miura G: [Tuberous sclerosis with intraventricular tumor presenting the symptoms of obstructive hydrocephalus]. CT Kenkyu 6: 571-575, 1984 (Jpn, with Eng abstract)

10) Jervis GA: Spongioneuroblastoma and tuberous sclerosis. J Neuropathol Exp Neurol 13: 105-116, 1954

11) Kingsley DPE, Kendall BE, Fitz CR: Tuberous sclerosis: A clinicoradiological evaluation of 110 cases with particular reference to atypical presentation. Neuroradiology 28: 38-46, 1986

12) Kitanaka $C$, Shitara $N$, Nakagomi $T$, Nakamura $H$, Genka S, Nakagawa K, Akanuma A, Aoyama H, Takakura K: Postradiation astrocytoma. I Neurosurg 70: $469-474,1989$

13) Lang FF, Miller DC, Koslow M, Newcomb EW: Pathways leading to glioblastoma multiforme: A molecular analysis of genetic alterations in 65 astrocytic tumors. J Neurosurg 81: 427-436, 1994

14) MacCarty WC Jr, Russell DG: Tuberous sclerosis: Report of a case with ependymoma. Radiology 71: 833-838, 1958

15] Morimoto K, Mogami H: Sequential CT study of subependymal giant-cell astrocytoma associated with tuberous sclerosis. J Neurosurg 65: 874-877, 1986

16) Nagib MG, Haines SJ, Erickson DL, Mastri AR: Tuberous sclerosis: A review for the neurosurgeon. Neurosurgery 14: 93-98, 1984

17) Padmalatha C, Harruff RC, Ganick D, Hafez GR: Glioblastoma multiforme with tuberous sclerosis. Arch Pathol Lab Med 104: 649-650, 1980

18) Puech P, Lereboullet J, Bernard P: Sclerose tubereuse et tumerurs cerebrales. Rev Neurol (Paris) 77: 225246, 1945

19) Rocco CD, Iannelli $A$, Marchese $E$ : On the treatment of subependymal giant cell astracytoma and associated hydrocephalus in tuberous sclerosis. Pediatr Neurosurg 23: 115-121, 1995

20) Salavati M, Artico M, Caruso R, Rocchi G, Orlando ER, Nucci F: A report on radiation-induced gliomas. Cancer 67: 392-397, 1991

21) Sampson JH, Martuza RL: Neurofibromatosis and other phakomatoses, in Wilkins RH, Rengachary SS (eds): Neurosurgery, ed 2. New York, McGraw-Hill, 1996, pp 677-681

22) Shapiro S, Mealey J, Sartorius C: Radiation-induced intracranial malignant gliomas. J Neurosurg 71: 77- 
82,1989

23) Shepherd CW, Scheithauer BW, Gomez MR, Altermatt HJ, Katzmann JA: Subependymal giant cell astrocytoma: A clinical, pathological, and flow cytometric study. Neurosurgery 28: 864-868, 1991

24) Shitara N, Yoshida J, Kageyama N, Takakura K: Clinical aspects of tuberous sclerosis and associated tumors, in Ishibashi Y, Hori Y (eds): Tuberous Sclerosis and Neurofibromatosis: Epidemiology, Pathophysiology, Biology and Management. Elsevier Science Publishers BV (Biomedical Division), 1990, pp 323-330

25) Sinson G, Sutton LN, Yachnis AT, Duhaime A, Schut L: Subependymal giant cell astrocytomas in children. Pediatr Neurosurg 20: 233-239, 1994
26) Tsuchida T, Kamata K, Kawamata M, Okada K, Tanaka R, Oyake Y: Brain tumors in tuberous sclerosis: Report of 4 cases. Childs Brain 8: 271-283, 1981

27) Watkins D, Rouleau GA: Genetics, prognosis and therapy of central nervous system tumors. Cancer Detect Prev 18: 139-144, 1994

Address reprint requests to: H. Matsumura, M.D., Department of Neurosurgery, Osaka University Medical School, 2-2 Yamadaoka, Suita, Osaka 565-0871, Japan. 